\title{
Pengaruh Emotional Freedom Technique (EFT) Terhadap Gambaran Diri Pasien Kanker Payudara di Yogyakarta
}

\section{The Effect of Emotional Freedom Technique (EFT) on Body Image of Breast Cancer Patients in Yogyakarta}

\author{
Eki Resti Anggreini ${ }^{1 *}$, Ike Wuri Winahyu Sari² \\ ${ }^{1}$ Program Studi IImu Keperawatan, Fakultas Kesehatan, Universitas Jenderal Achmad Yani, \\ Yogyakarta \\ 2Departemen Keperawatan Medikal Bedah, Program Studi IImu Keperawatan, Fakultas \\ Kesehatan, Universitas Jenderal Achmad Yani, Yogyakarta
}

\begin{abstract}
Background: Mastectomy and chemotherapy have side effects that can affect the body image of breast cancer patients. The Emotional Freedom Technique (EFT) is a complementary alternative medicine that has the power of tapping and suggestion that can correct physical and psychological problems in just minutes.

Objective: The aim of this study was to determine the effect of EFT on the body image of breast cancer patients in one of hospital in Yogyakarta.

Methods: This study used a pre-experimental design with one group pre-test and post-test designs. The sampling used purposive sampling technique with a sample size of 17 respondents. The body image was measured using a valid and reliable Body Image Scale (BIS). Data were analysed using the Wilcoxon test.

Results: The body image of breast cancer patients before being given an EFT showed a median value of 8,00 (range of score from 0-30). Meanwhile, respondent's body image after being given EFT showed a median value of 4,00 (range of score $0-30$ ). Wilcoxon test results obtained a $p$-value of $<0,001$, which means that there was a significant effect of EFT on the body image of breast cancer patients.

Conclusion: There is an effect of EFT on the body image of breast cancer patients. EFT therapy is a non-pharmacological alternative therapy that can be applied to improving negative body image in breast cancer patients.
\end{abstract}

Keywords: body image, breast cancer, EFT

\section{ABSTRAK}

Latar Belakang: Pengobatan kanker payudara seperti mastektomi ataupun kemoterapi memiliki efek samping yang dapat memengaruhi gambaran diri pasien kanker payudara. Emotional Freedom Technique (EFT) merupakan pengobatan komplementer alternatif yang mempunyai kekuatan tapping dan sugesti yang bisa memperbaiki masalah fisik dan psikologis hanya dalam waktu hitungan menit.

Tujuan: Untuk mengetahui pengaruh Emotional Freedom Technique (EFT) terhadap gambaran diri pasien kanker payudara di Yogyakarta.

Metode: Penelitian ini menggunakan desain pre experiment dengan rancangan one group pretest and posttest. Teknik pengambilan sampel menggunakan purposive sampling dengan jumlah sampel sebanyak 17 responden. Gambaran diri diukur menggunakan Body Image Scale (BIS) yang telah valid dan reliabel. Analisis data menggunakan uji Wilcoxon.

Hasil: Gambaran diri pasien kanker payudara sebelum diberikan EFT menunjukkan nilai median 8,00 (rentang skor 0-30). Sementara gambaran diri responden setelah diberikan EFT menunjukkan nilai median 4,00 (rentang skor 0-30). Hasil uji Wilcoxon diperoleh $p$-value $<0,001$.

Kesimpulan: Terdapat pengaruh EFT terhadap gambaran diri pasien kanker payudara. Terapi EFT merupakan pengobatan alternatif non farmakologi yang dapat diterapkan dalam memperbaiki gambaran diri yang negatif pada pasien kanker payudara.

Kata Kunci: EFT, gambaran diri, kanker payudara 


\section{PENDAHULUAN}

Kanker payudara merupakan pertumbuhan sel yang abnormal dan tidak terkontrol pada jaringan payudara yang sering terjadi pada wanita. ${ }^{1}$ Globocan International Agency for Research on Cancer (IARC), ${ }^{2}$ menyebutkan bahwa insiden kanker payudara menempati urutan pertama penyebab kematian (627.000 kematian, 6,6\%) dan wanita terdiagnosa kanker payudara sebanyak 24,2\%. Prevalensi kanker di Indonesia pada tahun 2013 sebesar 1,4\% yaitu sekitar 347.792 orang. Provinsi dengan prevalensi paling tinggi untuk penyakit kanker berada di Daerah Istimewa Yogyakarta (DIY) yaitu sebesar 4,1\% atau sekitar 14.596 orang. ${ }^{3}$

Seringkali penderita kanker terlambat mencari pengobatan. Sekitar 60-70\% penderita datang untuk melakukan pengobatan pada saat penyakit telah memasuki stadium lanjut (stadium III dan IV). Pada stadium ini perlu dilakukan pengobatan seperti pembedahan, mastektomi, radiasi, kemoterapi, dan terapi hormon maupun kombinasi di antara jenis pengobatan tersebut. ${ }^{4,5}$ Efek samping dari pengobatan akan menimbulkan dampak di antaranya mual, muntah, rambut rontok, keletihan, nyeri, hilangnya sebagian jaringan pada payudara dan lain-lain yang akan menyebabkan perubahan diri pasien. ${ }^{5}$

Gambaran diri merupakan konsep subjektif terhadap penampilan fisik, bentuk tubuh, ukuran tubuh, dan fungsi tubuh, di mana setiap orang dan keluarga memiliki reaksi berbeda tergantung jenis perubahan yang dialami. Saat terdapat perubahan gambaran diri, reaksi klien umumnya menyesuaikan diri dalam fase syok, menarik diri, mengakui, menerima, dan rehabilitasi. ${ }^{6}$ Pada pasien kanker payudara sebanyak $74,8 \%$ wanita melaporkan ketidakpuasan dengan gambaran dirinya setelah melakukan pengobatan. ${ }^{7}$

Tingginya tingkat ketidakpuasan pasien kanker payudara pada tubuhnya membuat hal ini menjadi salah satu fokus masalah yang perlu penatalaksanaan. Penatalaksanaan yang dapat diberikan salah satunya berupa pengobatan komplementer alternatif yaitu terapi Emotional Freedom Technique (EFT).

Emotional Freedom Technique (EFT) atau teknik kebebasan emosi adalah alat terapi psikologi yang diterapkan berdasarkan teori yang menyatakan bahwa emosi yang berlebihan pada dasarnya bersifat negatif. ${ }^{8}$ EFT dilakukan dengan cara tapping atau mengetuk ringan titik-titik meridian untuk mengirim sinyal yang dapat berefek menenangkan otak. EFT dapat diterapkan untuk menyembuhkan berbagai persoalan baik gejala emosional, pembentukan perilaku positif maupun menghilangkan sakit fisik. ${ }^{9}$ Terapi ini memiliki berbagai manfaat seperti menghilangkan fobia, trauma, sakit fisik, sakit cinta, cemas, rasa takut, sedih, dan permasalahan besar maupun kecil hanya dengan teknik tapping (ketukan ringan), dan dalam satu menit masalah akan hilang. ${ }^{8}$

Berdasarkan hasil studi pendahuluan yang dilakukan oleh peneliti di salah satu rumah sakit pemerintah di Bantul pada tanggal 9 - 12 Maret 2019 didapatkan hasil bahwa jumlah populasi pasien kanker payudara dari bulan Januari - Februari 2019 sebanyak 58 pasien 
dengan jumlah kunjungan sebanyak \pm 10 pasien setiap bulan di poli bedah. Pasien yang sedang aktif menjalani pengobatan mayoritas telah menjalani mastektomi dan lebih dari 6 kali menjalani kemoterapi. Paska pengangkatan payudara pasien merasakan ada yang kurang dengan dirinya, merasa tidak memiliki keutuhan sebagai perempuan, dan mati rasa di bagian luka akibat pengangkatan payudara. Pasien juga merasakan efek dari kemoterapi seperti rambut rontok, mual dan muntah. Satu pasien mengatakan pasrah menerima keadaan karena merasa sudah tua. Sejauh ini pasien belum pernah mendapatkan pengobatan komplementer alternatif atau pengobatan herbal, mereka lebih memilih pengobatan medis.

Berdasarkan hasil studi pendahuluan tersebut bahwa pasien dengan kanker mengalami permasalahan body image, mereka belum mengakses pelayanan komplementer khususnya terapi EFT untuk mengurangi permasalahan body image. Sejauh penelaahan literatur, penelitian pengaruh EFT terhadap gambaran diri pada pasien kanker payudara masih jarang dilakukan. Oleh karena itu penelitian terkait hal ini patut untuk dilakukan.

Tujuan penelitian ini adalah untuk mengetahui pengaruh pengaruh EFT terhadap gambaran diri pada pasien kanker payudara.

\section{METODE PENELITIAN}

Penelitian ini menggunakan desain pre-experimental dengan rancangan penelitian one group pre-test and post-test. Penelitian ini dilakukan di poliklinik bedah dan onkologi di salah satu rumah sakit pemerintah di daerah Bantul. Pengambilan data dilakukan tanggal 1-18 Juli 2019 dengan melibatkan 17 responden yang diambil menggunakan teknik purposive sampling. Kriteria inklusi pada penelitian ini adalah pasien wanita yang terdiagnosa kanker payudara oleh dokter, mendapatkan pengobatan mastektomi dan atau kemoterapi, dan tidak mengalami gangguan mobilitas.

Alat pengumpulan data yang digunakan yaitu lembar karakteristik reponden dan kuesioner Body Image Scale (BIS) yang berisi 10 item pertanyaan menggunakan skala likert yang telah dilakukan uji validitas dan reliabilitas oleh peneliti sebelumnya dan didapatkan $r$ 0,529-0,914 dan nilai cronbach alpha 0,194. Instrumen ini dinyatakan valid dan reliabel. Interprestasi kuesioner BIS yaitu jumlah skor minimal 0 dan jumlah skor maksimal 30, semakin rendah skor maka semakin baik gambaran diri pasien kanker payudara. Uji statistik yang digunakan yaitu uji Wilcoxon untuk mengetahui pengaruh EFT terhadap gambaran diri pasien kanker payudara.

Responden diberikan perlakuan terapi EFT sebanyak 3 kali. Perlakuan pertama di berikan oleh peneliti selama 10-20 menit, setelah selesai responden diberikan Standar Operating Prosedur (SOP) EFT sebagai panduan ketika melakukan terapi mandiri. Perlakuan yang ke dua dilakukan mandiri oleh responden selama di rumah masih dengan pantauan peneliti 
menggunakan media telekomunikasi, sementara perlakuan ke tiga sekaligus evaluasi dilakukan ketika responden melakukan kunjungan ke poliklinik.

Penelitian ini telah mendapatkan persetujuan etik penelitian dari Komite Etik Fakultas Kesehatan Universitas Jenderal Achmad Yani Yogyakarta dengan nomor: Skep/043/KEPK/V/2019 yang dikeluarkan pada tanggal 06 Mei 2019. Semua responden dalam penelitian ini telah menandatangani informed consent.

Selama proses pengambilan data, peneliti dibantu oleh asisten peneliti yaitu mahasiswa yang berlatar belakang pendidikan S1 IImu keperawatan di Universitas Jenderal Achmad Yani Yogyakarta yang sebelumnya sudah dilakukan persamaan persepsi mengenai cara pengisian lembar kuesioner gambaran diri dan prosedur terapi EFT. Asisten peneliti sebagai fasilitator selama peneliti memberikan perlakuan EFT sesuai dengan prosedur.

\section{HASIL}

Karakteristik responden pada penelitian ini tercantum pada Tabel 1. Tabel 1 menunjukkan bahwa rata-rata usia responden yaitu 50,25 $\pm 8,08$ tahun. Sementara nilai median lama responden terdiagnosis kanker payudara adalah 12 bulan. Seluruh responden (100\%) beragama Islam. Mayoritas responden berpendidikan SD dan SMA, bekerja sebagai ibu rumah tangga, berstatus menikah dan memiliki suami yang merupakan pendamping pengobatan. Sementara stadium klinis terbanyak responden yaitu di stadium 3 dan mayoritas responden menjalani rawat jalan. Pengobatan yang telah dijalani responden paling banyak yaitu kombinasi antara pembedahan, kemoterapi, dan obat oral.

Gambaran diri pasien kanker payudara sebelum dan sesudah diberikan intervensi EFT tercantum pada Tabel 2. Tabel 2 menunjukkan bahwa gambaran diri pasien kanker payudara sebelum diberikan intervensi EFT memiliki nilai median yaitu 8,00 (4,00-9,50). Sementara gambaran diri responden setelah diberikan intervensi EFT menunjukkan nilai median yaitu $4,00(2,00-5,00)$. 
Tabel 1. Karakteristik responden pasien kanker payudara $(n=17)$

\begin{tabular}{|c|c|c|c|}
\hline Karakteristik & $f(\%)$ & Mean $\pm S D$ & $\begin{array}{c}\text { Median } \\
\text { (IQR) }\end{array}$ \\
\hline Usia (tahun) & & $50,25 \pm 8,08$ & \\
\hline Lama terdiagnosis (bulan) & & & $\begin{array}{c}12,00 \\
(2,00-48,00)\end{array}$ \\
\hline $\begin{array}{l}\text { Agama } \\
\text { Islam }\end{array}$ & $17(100,0)$ & & \\
\hline $\begin{array}{l}\text { Pendidikan } \\
\text { SD } \\
\text { SMP } \\
\text { SMA } \\
\text { Perguruan Tinggi }\end{array}$ & $\begin{array}{l}6(35,3) \\
2(11,8) \\
6(35,3) \\
3(17,6)\end{array}$ & & \\
\hline $\begin{array}{l}\text { Pekerjaan } \\
\text { IRT } \\
\text { PNS/Pegawai Swasta } \\
\text { Wiraswasta } \\
\text { Tani } \\
\text { Buruh } \\
\end{array}$ & $\begin{array}{c}5(29,5) \\
4(17,6) \\
3(23,5) \\
1(5,9) \\
4(23,5) \\
\end{array}$ & & \\
\hline $\begin{array}{l}\text { Status pernikahan } \\
\text { Menikah } \\
\text { Janda }\end{array}$ & $\begin{array}{l}15(88,2) \\
2(11,8) \\
\end{array}$ & & \\
\hline $\begin{array}{l}\text { Stadium klinis } \\
\text { Stadium I } \\
\text { Stadium } 2 \\
\text { Stadium } 3 \\
\text { Stadium } 4 \\
\end{array}$ & $\begin{array}{c}4(23,5) \\
4(23,5) \\
8(47,1) \\
1(5,9) \\
\end{array}$ & & \\
\hline $\begin{array}{l}\text { Pendamping utama pengobatan } \\
\text { Orang Tua } \\
\text { Suami } \\
\text { Anak } \\
\text { Keluarga } \\
\text { Sendiri }\end{array}$ & $\begin{array}{c}1(5,9) \\
10(58,8) \\
2(11,8) \\
3(11,6) \\
1(5,9) \\
\end{array}$ & & \\
\hline $\begin{array}{l}\text { Perawatan saat Ini } \\
\text { Rawat Inap } \\
\text { Rawat Jalan }\end{array}$ & $\begin{array}{c}1(5,9) \\
16(94,1)\end{array}$ & & \\
\hline $\begin{array}{l}\text { Pengobatan yang telah dijalani } \\
\text { Pembedahan } \\
\text { Kombinasi: Pembedahan dan obat oral } \\
\text { Kombinasi: Pembedahan, Kemoterapi, dan obat oral } \\
\text { Kombinasi: Pembedahan, kemoterapi, } \\
\text { radiasi/penyinaran, obat oral } \\
\text { Kombinasi: Pembedahan dan kemoterapi }\end{array}$ & $\begin{array}{l}3(17,6) \\
2(11,8) \\
8(47,1) \\
3(17,6) \\
1(5,9) \\
\end{array}$ & & \\
\hline
\end{tabular}

Pengaruh EFT terhadap gambaran diri pasien kanker payudara tercantum pada Tabel 2. Tabel 2 menunjukkan hasil uji Wilcoxon diperoleh tingkat signifikansi $p<0,001$. Hasil tersebut menunjukkan bahwa terdapat pengaruh yang signifikan antara intervensi Emotional Freedom Technique (EFT) terhadap gambaran diri pasien kanker payudara.

Tabel 2. Pengaruh EFT terhadap gambaran diri pasien kanker payudara $(n=17)$

\begin{tabular}{lcc}
\hline Intervensi EFT & Median (IQR) & p-value \\
\hline Sebelum Intervensi & $8,00(4,00-9,50)$ & $<0,001^{*}$ \\
\hline Sesudah Intervensi & $4,00(2,00-5,00)$ & \\
\hline${ }^{*}$ Signifikan dengan $p<0,01$ & &
\end{tabular}




\section{PEMBAHASAN}

Usia penderita kanker payudara pada penelitian ini rata-rata berusia 50,25 $\pm 8,08$ tahun. Usia merupakan faktor risiko penyakit kanker payudara. Usia lebih dari 30 tahun kemungkinan lebih besar berisiko mendapatkan penyakit kanker payudara. ${ }^{10}$ Sementara lama terdiagnosis kanker payudara adalah 12 bulan, paling cepat terdiagnosis yaitu 2 bulan dan paling lama 48 bulan. Penelitian yang dilakukan oleh Pakpahan, ${ }^{11}$ mendapati bahwa lama terdiagnosis paling banyak $<2$ tahun sebanyak 29 responden $(55,8 \%)$ dan telah menjalani pengobatan paling banyak 0-12 bulan, yaitu sebanyak 33 responden (63,5\%). Responden yang telah berobat telah memasuki stadium klinis terbanyak yaitu stadium 3 . Kemenkes $\mathrm{RI},{ }^{4}$ menyatakan bahwa seringkali hampir 60-70\% penderita kanker payudara datang untuk melakukan pengobatan saat penyakit telah memasuki stadium lanjut (stadium 3 dan 4). Stadium kanker biasanya mulai diketahui pada stadium 2, karena pada stadium ini telah muncul benjolan dan berubah menjadi besar dan sudah menyebar di kelenjar getah bening aksila (ketiak) serta berukuran 2 hingga $5 \mathrm{~cm}$. Perawatan responden saat ini yang sedang dilakukan responden yaitu mayoritas rawat jalan sebanyak 16 responden $(94,1 \%)$, sedangkan pengobatan yang telah dijalani responden paling banyak yaitu kombinasi antara pembedahan, kemoterapi, dan obat oral sebanyak 8 responden.

Terapi EFT yang bertujuan untuk memperbaiki gambaran diri pasien kanker payudara sampai saat ini belum pernah diteliti. Berdasarkan hasil penelitian yang telah dilakukan, didapatkan nilai tengah gambaran diri penderita kanker payudara sebelum diberikan intervensi EFT berada pada skor 8,00 (rentang skor 0-30) dengan skor tertinggi 24,00 dan terendah 2,00. Sementara setelah diberikan intervensi EFT nilai tengah gambaran diri penderita kanker payudara menjadi 4,00 (rentang skor 0-30) dengan skor tertinggi 16,00 dan terendah 1,00. Penurunan skor median dari 8,00 menjadi 4,00 menunjukkan bahwa gambaran diri pasien kanker payudara menjadi positif dengan nilai $p<0,001$.

Hasil penelitian yang dilakukan oleh Sandhi, Azza, dan Komarudin, ${ }^{12}$ menyatakan bahwa pasien kanker payudara memiliki gambaran diri negatif dengan jumlah 34 responden $(54,0 \%)$ dan gambaran diri positif sebanyak 29 responden (46,0\%). Sementara hasil penelitian Nurhayati, ${ }^{13}$ pada 29 responden kanker payudara bahwa responden memiliki gambaran diri yang cukup yaitu sebanyak 16 responden (55,2\%). Hasil penelitian Guntari dan Suariyani, ${ }^{14}$ mengatakan bahwa penderita kanker payudara yang menilai dirinya negatif dan cenderung tidak puas dengan penampilannya, hal ini menyebabkan individu menampilkan kesan negatif dalam memandang dirinya, seperti rasa malu dan rendah diri terhadap orang lain karena keadaan fisik yang tidak sempurna dan tidak sesuai dengan yang diharapkan.

Hasil penelitian yang dilakukan oleh Pakpahan, ${ }^{11}$ pada 52 responden kanker payudara post mastektomi didapatkan hasil bahwa mayoritas responden memiliki gambaran diri positif yaitu sebanyak 43 responden (82,7\%). Pada umumnya, pasien kanker payudara yang memiliki 
keinginan untuk sembuh yang tinggi dan merasa lebih tenang setelah melakukan mastektomi dengan asumsi bahwa penyakit kanker yang ada dipayudaranya telah diangkat karena pada dasarnya penderita kanker payudara tersebut lebih mementingkan kesembuhannya dibandingkan penampilan. Penderita juga mengaku pasrah kepada Tuhan dan berusaha menerima segala sesuatu yang akan terjadi pada dirinya, karena mereka percaya bahwa hidup dan mati seseorang ada di tangan Tuhan. ${ }^{15}$

Hasil penelitian ini menunjukkan terdapat pengaruh terapi EFT terhadap gambaran diri pasien kanker payudara. EFT merupakan terapi yang dapat digunakan untuk menyembuhkan berbagai masalah baik gejala emosional maupun sakit fisik. EFT disebut versi modern terapi energi. EFT dikembangkan dari akupuntur atau memiliki persamaan dengan akupresur, namun sesungguhnya ada perbedaan antara EFT dengan berbagai terapi tersebut. EFT memiliki berbagai manfaat dalam mengatasi masalah seperti gangguan emosional meliputi rasa cemas, takut, fobia, stres, trauma, sedih dan gangguan emosi lainnya. EFT juga dapat mengatasi masalah fisik manusia seperti rasa sakit maupun nyeri, gangguan gambaran diri, dan perilaku adiktif. ${ }^{9}$

Langkah-langkah kerja EFT ini diklasifikasikan dalam 3 tahap yaitu persiapan (set-up), pengetukan (tapping), dan evaluasi. Pada tahap pengetukan (tapping) dilakukan dengan mengetuk lembut titik meridian menggunakan jari tangan disertai dengan afirmasi yang telah disiapkan. Titik meridian memiliki fungsi masing-masing bekerja langsung dalam organ tubuh yang menstimulus energi emosional. Terdapat 14 titik meridian beserta fungsinya meliputi puncak kepala ( $T o p-H e a d=T H$ ) titik dimana pertemuan berbagai meridian yang terkoneksi dengan otak limbig dan berfungsi mengurangi rasa tegang. ${ }^{9}$

Titik meridian pangkal dalam mata (Eyebrow) titik ini terkoneksi dengan kandung kemih yang berfungsi menghilangkan rasa sedih, kegelisahan, ketidaksabaran, frustasi, pembalikan psikologis, fobia, dan trauma. Titik bagian luar mata atau pelipis (Slide of Eye) titik ini terkoneksi dengan empedu berfungsi menghilangkan rasa benci, atau permusuhan. Titik tengah tulang bawah mata (Under Eye) terkoneksi dengan perut berfungsi menyembuhkan rasa gelisah, rasa jijik, cemas, gugup dan adiktif. Bawah hidung (Under Nose) terkoneksi dengan otak kiri dan kakan untuk menyeimbangkan perasaan cemas gagal dan rasa malu. Bawah bibir (Chin) terkoneksi dengan hati berfungsi untuk mengembangkan percaya diri dari penghapusan emosi dan rasa malu. Collarbone bawah tulang silika terkoneksi dengan ginjal berfungsi menghapus rasa tidak aman atau rasa takut. Bawah ketiak (Under Arm) terkoneksi dengan limpa dapat menyembuhkan rasa cemas, rendah diri, dan dorongan adiktif. ${ }^{9}$

Titik meridian pada jempol ( Thumb) terkoneksi dengan paru-paru dapat mengatasi emosi, sedih, atau merasa terhina, arogansi, dan obsesif-kompulsif. Jari telunjuk terkoneksi dengan usus besar untuk menghilangkan rasa bersalah atau penyesalan. Jari tengah berkaitan dengan organ perut untuk menyembuhkan rasa cemburu, kegelisahan, dorongan adiktif, 
masalah seksual, dan alergi. Jari kelingking terkoneksi dengan jantung untuk meredakan kesedihan, kemarahan, agresivitas, atau rasa dendam. Pinggir tangan (Karate Cup) untuk lebih menerima diri secara ikhlas dengan masalah yang dihadapi. Titik terakhir yaitu titik gamut pada punggung tangan dengan jari manis. Titik ini terkoneksi dengan limpa untuk menyembuhkan depresi, kesepian, keputus-asaan, dan juga dapat digunakan untuk keseimbangan otak kiri dan kanan perawatan kecemasan dan dorongan adiktif serta pengobatan rasa sakit. Titik ini yang mendasari efek yang dirasakan oleh tubuh dari terapi EFT. ${ }^{9}$ Melalui 3 tahap dan stimulasi tapping di titik meridian tersebut, itulah yang menjadi alasan EFT efektif dalam mengatasi masalah psikologis maupun fisik.

Hasil wawancara umum kepada pasien kanker payudara pada penelitian ini mengenai sudut pandang individu terhadap gambaran dirinya bahwa secara umum pasien tidak terjadi masalah dari segi penampilan dan dalam berbusana. Pasien merasa dirinya kurang utuh tidak sempurna seperti sebelumnya karena efek pengangkatan payudara disalah satu bahkan kedua payudaranya. Pasien merasa tidak feminim lagi tetapi seperti laki-laki karena bentuk payudara yang datar, memiliki masalah kurang menarik secara seksualitas.

Status pernikahan merupakan salah satu faktor yang memengaruhi gambaran diri. Pada wanita yang telah menikah yang telah melakukan mastektomi akan merasa malu terhadap pasanganya mengenai keadaan fisik yang sekarang, sehingga hubungan suami dan istri menjadi tidak maksimal dan khawatir apabila anak perempuan mereka mengalami hal yang sama. Sementara pada wanita yang belum menikah cenderung merasa malu dengan keadaan fisiknya, khawatir akan dikucilkan oleh teman-teman serta takut tidak dapat jodoh. ${ }^{16}$

Terapi EFT menggunakan kalimat sugesti (afirmasi) yang mendorong pasien untuk mengubah pola fikir menjadi positif. ${ }^{16}$ EFT memiliki manfaat seperti mengatasi kegelisahan, mengatasi tekanan, gangguan pikiran, perubahan gambaran diri serta kesedihan. ${ }^{8}$ Setelah dilakukan terapi EFT terdapat beberapa responden mengatakan merasa lebih tenang, nyaman, dan ikhlas dengan yang sudah terjadi.

Reaksi yang dirasakan setelah pengetukan (tapping) terjadi karena respon jaringan saraf sensorik sampai dengan saraf sentral. Jaringan saraf berkomunikasi satu dengan yang lain melalui neurotransmiter di sinapsis. Stimulasi di jaringan perifer akan berlanjut ke sentral melalui medula spinalis batang otak menuju hipothalamus dan hipofisis sehingga menghasilkan efek terhadap sekresi neurotransmiter seperti endorfin, norepinefrin, dan enkefalin. 5-HT (serotonin) yang berperan sebagai inhibisi sensasi nyeri. Sekresi neurotransmiter ini juga berperan dalam sistem imun sebagai imunomodulator serta perbaikan fungsi organ lainya, seperti pada penyakit psikiatrik. Hal inilah yang berperan mengatasi gangguan mood, kecemasan serta pikiran negatif. ${ }^{15}$ 


\section{KESIMPULAN DAN SARAN}

Gambaran diri pasien kanker payudara setelah diberikan intervensi EFT memiliki skor median lebih rendah dibandingkan dengan skor media sebelum intervensi. Hal ini menunjukkan gambaran diri pasien kanker payudara menjadi lebih baik setelah diberikan intervensi EFT sehingga dapat disimpulkan bahwa terdapat pengaruh Emotional Freedom Technique (EFT) terhadap gambaran diri pasien kanker payudara.

Terapi EFT menjadi salah satu pengobatan komplementer alternatif yang dapat meningkatkan gambaran diri pasien kanker payudara. Terapi ini dapat diterapkan di rumah sakit agar dalam asuhan keperawatan tidak hanya berfokus pada masalah fisik saja. Pasien juga dapat diedukasi supaya dapat melakukan terapi EFT secara mandiri di rumah.

\section{UCAPAN TERIMAKASIH}

Ucapan terima kasih peneliti sampaikan kepada semua pihak yang telah membantu dan terlibat dalam penelitian ini.

\section{DAFTAR PUSTAKA}

1. Osborn K, Wraa C, Watson A, Holleran R. Medical-Surgical Nursing, 2nd Edition. USA: Pearson; 2014.

2. International Agency for Research on Cancer (IARC). Latest global cancer data: Cancer burden rises to 18.1 million new cases and 9.6 million cancer deaths in 2018 - IARC. WHO. 2018.

3. Kementerian Kesehatan RI. Pusat Data dan Informasi Kementrian Kesehatan. Jakarta: Kementerian Kesehatan RI; 2015.

4. Kementerian Kesehatan RI. Pusat Data dan Informasi Kementrian Kesehatan: Kanker Payudara. Jakarta: Kementerian Kesehatan RI; 2016.

5. Potter P, Perry A. Fundamental Keperawatan. Jakarta: Salemba Medika; 2005.

6. Potter P, Perry A. Fundamental Keperawatan, Edisi 7. Jakarta: Salemba Medika; 2010.

7. Guedes T, Dantas de Oliveira N, Holanda A, Reis M, Silva C, Rocha e Silva B, et al. Body Image of Women Submitted to Breast Cancer Treatment. Asian Pac J Cancer Prev. 2018 Jun 1;19(6):1487-93.

8. Iskandar E. The Miracle of Touch. Bandung: Mizan Pustaka; 2010.

9. Sutja A. Emotional Freedom Technique Cara Cepat Mengatasi Gangguan Emosi \& Penyakit Fisik. Bandung: Alfabeta; 2018.

10. Nurianti S. Faktor-Faktor Yang Berhubungan Dengan Kejadian Kanker Payudara Di Rumah Sakit Murni Teguh Medan Tahun 2017. J Ilm Simantek. 2017;1(4):50-63.

11. Pakpahan STM. Gambaran Diri Wanita Penderita Kanker Payudara Post Mastektomi di RSUP H. Adam Malik Medan [Skripsi]. Medan: Univesitas Sumatera Utara; 2018.

12. Sandhi AK, Azza A, Komarudin. Hubungan Perubahan Citra Tubuh Dengan Kemampuan Adaptasi Psikososial Pasien Kanker Dengan Kemoterapi Di RS Tingkat III Baladhika Husada Jember [Skripsi]. Vol. 13. Jember: Universitas Muhammadiyah Jember; 2017.

13. Nurhayati S, Nofiyanto M. Hubungan Citra Tubuh dengan Kualitas Hidup Pasien Kanker Payudara di RSUD Panembahan Senopati Bantul [Skripsi]. 2018 [cited 2021 Jul 31]; Available from: http://www.unjaya.ac.id

14. Guntari GAS, Suariyani NLP. Gambaran Fisik dan Psikologis Penderita Kanker Payudara Post Masektomi di RSUP Sanglah Denpasar Tahun 2014. Arch Community Heal. 2016;3(1):24-35.

15. Sriwahyuningsih, Dahrianis, Askar M. Faktor yang Berhubungan dengan Gangguan Citra Tubuh (Body Image) pada Pasien Post Mastektomi di RSUP Dr. Wahidin Sudirihusodo Makasar. J IIm Kesehat Diagnosis. 2012;1(3).

16. Ningsih SF, Karim D, Sabrian F. Efektivitas Terapi Emotional Freedom Technique (EFT) Terhadap Kecemasan Pasien Kanker Payudara Stadium II dan III. J Online Mhs. 2015 Nov 27;2(2):1501-9. 